\title{
The expression of platelet serotonin transporter (SERT) in human obesity
}

\author{
Gino Giannaccini ${ }^{1 *}$, Laura Betti ${ }^{1}$, Lionella Palego ${ }^{2}$, Alessandro Marsili ${ }^{2}$, Ferruccio Santini ${ }^{2}$, Caterina Pelosini ${ }^{2}$, \\ Laura Fabbrini ${ }^{3}$, Lara Schmid ${ }^{1}$, Laura Giusti ${ }^{1}$, Margherita Maffei ${ }^{4}$, Mario Lanza ${ }^{1}$, Mario Cristofaro ${ }^{1}$, Stefano Baroni ${ }^{2}$, \\ Mauro Mauri ${ }^{2}$, Paolo Vitti ${ }^{2}$, Paola Fierabracci ${ }^{5}$ and Antonio Lucacchini ${ }^{1}$
}

\begin{abstract}
Background: Serotonin (5-HT) is a well-known modulator of eating behavior. However, the molecular mechanisms linking its action to body weight balance have been only partially elucidated. Since platelets are a suitable peripheral model to study 5-HT transport, metabolism and release, we herein evaluated the expression of the platelet 5-HT re-uptake system (SERT) by $\left.{ }^{3} \mathrm{H}\right]$-paroxetine binding assay. A cohort of 114 unrelated individuals (34 males, 80 females; age, mean \pm SD: $38.57 \pm 12.47$ years) without major psychiatric disorders, was recruited following a naturalistic design regarding age or gender and classified accordingly to their body mass index (BMI). Subjects were divided into 5 groups: normal-weight (NW), overweight (OW) and grade I-III obese (OB) individuals. For gender analyses, data were transformed into $\left.{ }^{3} \mathrm{H}\right]$-paroxetine density $\left(\mathrm{B}_{\mathrm{max}}\right) / \mathrm{BMl}$ ratios to overcome both the disparity of women vs. men number and anthropometric differences between sexes.
\end{abstract}

Results: $\left.{ }^{3} \mathrm{H}\right]$-paroxetine $B_{\max }$ (SERT density, fmol/mg proteins) was reduced in platelet membranes of grade II $(p<0.01)$ and III $(p<0.001)$ obese subjects vs. controls and in overweight subjects $(p<0.05)$ vs. grade III obese individuals. Considering all patients together, a strong negative correlation between $B_{\max }$ and $B M I(r=-0.449 ; P<0.0001)$ was demonstrated. Conversely, $\left[{ }^{3} \mathrm{H}\right]$-paroxetine $\mathrm{K}_{\mathrm{D}}$ (dissociation constant, $\mathrm{nM}$ ) did not differ among groups. No gender-related variation concerning $B_{\text {max }} / B M I$ ratios was observed in this cohort of subjects.

Conclusions: The down-regulation of SERT in platelet membranes of severe human obesity $\left(\mathrm{BMI}>35 \mathrm{Kg} / \mathrm{m}^{2}\right.$ ) confirms the involvement of 5-HT system in body weight gain. Moreover, this findings may help to elucidate those monoamine-endocrine networks acting on fat storage, adipocyte signaling and energy balance. Targeting 5-HT/5-HT-related markers will possibly uncover the existence of human obesity subtypes.

Keywords: Human obesity, SERT expression, $\left[{ }^{3} \mathrm{H}\right]$-paroxetine binding, Platelets

\section{Background}

Among neurotransmitters linked to appetite control, serotonin (5-HT) has a particular role: this endogenous amine is tightly involved in the regulation of feeding behavior at hypothalamic level, acting within the ventromedial and lateral nuclei [1-3]. In fact, the activity of 5-HTergic raphe and hypothalamic neurons is influenced by meal macronutrient composition and insulin secretion, as suggested by the findings that the tryptophan/large neutral amino acids concentration ratio (Trp:LNAAs) in plasma

\footnotetext{
* Correspondence: gino.giannaccini@farm.unipi.it

'Department of Pharmacy, University of Pisa, via Bonanno 6, Pisa 56126-I, Italy

Full list of author information is available at the end of the article
}

(an index of Trp availability to brain uptake) and 5-HT synthesis are both increased after a carbohydrate-rich meal [4-8]. The same concept applies to protein-rich meals or meals containing proteins with high tryptophan content (e.g. $\alpha$-lactalbumin) [9], demonstrating the impact of diet upon tryptophan uptake, 5-HT production and synaptic release. On the other side, glucocorticoid response influences monoamine/5-HT transmission and receptor function in the central nervous system (CNS), thus affecting feeding behavior and macronutrient choice [10-13]. These observations clearly suggest a link between stress-response, 5-HT function, weight gain and obesity. Several studies indicate that obesity has, in most cases, a polygenic background [14-16]. Among others, genes coding for

\section{Biomed Central}


proteins involved in 5-HT system such as the 5-HT transporter (SERT or 5-HT-T) [17-21], carriers for neutral amino acids (including tryptophan) [22] and 5-HT receptor subtypes [23-28] appear to be functionally relevant in either animal or human obesity. From diet studies conducted in rodents and humans, the interest at targeting specific 5-HT sites and, in particular, SERT $[29,30]$ is strongly increased. Structurally, SERT is a glycoprotein belonging to the super-family of membranebound $\mathrm{NaCl}$-dependent neurotransmitter transporters, characterized by 12 putative membrane spanning domains: it promotes 5-HT clearance (re-uptake) from the extracellular milieu and modifies the sensitization state of 5-HT receptors within the nervous system or non-neural districts (gut, platelets, lymphomonocytes) [31,32]. It is a pharmacologically active site, the target of re-uptake inhibitors as tricyclic antidepressants (TCA) and Selective Serotonin Reuptake Inhibitors (SSRIs) or 5-HT releasers like fenfluramine and 3,4-methylenedioxy- $N$-methamphetamine (MDMA) [33]. Both SERT expression and 5HT uptake function are finely tuned by protein-kinases activities and gene transcription which control, following cell necessities, conformational changes of the membranebound SERT protein and/or the degree of SERT partition between cytoskeleton and plasma membrane [34-37].

Data on SERT expression/affinity in peripheral districts of overweight/obese subjects are currently not available. Platelets are a valuable peripheral model that mimics 5-HT transport, metabolism and release in the CNS, since they have been characterized for many years as a surrogate of impaired 5-HT activity in subjects with psychiatric disorders, eating behavior and ageing [38-44]. Therefore, the present study aimed to evaluate human platelets SERT number or affinity according to different categories of body mass index (BMI) or genders.

\section{Results}

\section{Subjects' groups}

As shown in Table 1, 114 individuals were recruited in the study and divided into 5 main BMI groups: 28 normal weight subjects (NWs), 18 overweight (OWs), 17 class I obese (OB-Is), 19 class II obese (OB-IIs) and 32 class III obese (OB-IIIs) individuals. ANOVA analysis showed a significant difference among BMIs of the groups $(\mathrm{p}<0.0001)$, without noticeable age variations $(\mathrm{p}>0.05)$.

\section{$\left[{ }^{3} \mathrm{H}\right]$-paroxetine binding experiments}

Equilibrium saturation and Scatchard analysis of $\left[{ }^{3} \mathrm{H}\right]$ paroxetine specific binding showed a single population of high-affinity recognition sites in platelet membranes from all the subjects under investigation, clearly indicating the labeling of a single protein. The specific binding was about $90 \%$ of total binding at the $\mathrm{K}_{\mathrm{D}}$ concentration. The $\left[{ }^{3} \mathrm{H}\right]$-paroxetine $B_{\max }$ (fmoles/mg protein) values, corresponding to SERT expression in platelet membranes, were: $1311 \pm 51.29$ (min.-max: 767-1795) in NWs; $1215 \pm$ 59.44 (min.-max: 665-1685) in OWs; $1137 \pm 70.36$ (min.max: 700-1700) in OB-Is; $986.4 \pm 89.73$ (min.-max.: 3441675) in OB-IIs; $906.8 \pm 58.51$ (min.-max: 336-1737) in OB-IIIs. The $\left[{ }^{3} \mathrm{H}\right]$-paroxetine $\mathrm{K}_{\mathrm{D}}$ values $(\mathrm{nM})$, corresponding to the SERT protein affinity state for the specific ligand, were: $0.092 \pm 0.009$ (min.-max: 0.028-0.20) in NWs; $0.073 \pm 0.0085$ (min.-max: 0.025-0.16) in OWs; $0.076 \pm 0.009$ (min.-max: 0.03-0.15) in OB-Is; $0.085 \pm$ 0.009 (min.-max: 0.038-0.19) in OB-IIs; $0.077 \pm 0.007$ (min.-max: 0.025-0.22) in OB-IIIs. Individual results for $\left[{ }^{3} \mathrm{H}\right]$-paroxetine $\mathrm{B}_{\max }$ and $\mathrm{K}_{\mathrm{D}}$, obtained from the $5 \mathrm{BMI}$ groups of subjects, are reported in Figure 1(a,b). ANOVA analysis showed a significant difference between the $\left[{ }^{3} \mathrm{H}\right]$ paroxetine $\mathrm{B}_{\max }$ means of the 5 BMI groups $(\mathrm{p}<0.0001)$; after the post-hoc Bonferroni correction test, $\mathrm{B}_{\max }$ mean values were significantly reduced in $\mathrm{OB}$ subjects class II-III $\left(\right.$ BMI $\left.>35 \mathrm{~kg} / \mathrm{m}^{2}\right)$ vs. NWs $(\mathrm{p}<0.01$ and $\mathrm{p}<0.001$, respectively) (Figure 1a); $B_{\max }$ values were also decreased in OB-IIIs respect to OWs $(\mathrm{p}<0.05)$ (Figure 1a).

\section{Correlation analyses and gender impact}

Among-groups differences in SERT expression were additionally sustained by the significant negative correlation between $\left[{ }^{3} \mathrm{H}\right]$-paroxetine $\mathrm{B}_{\max }$ and BMI both in the whole cohort ( $\mathrm{r}$ : $-0.449, \mathrm{p}<0.0001$; Figure $2 \mathrm{a}$ ) and by gender sub-analysis in women $(\mathrm{r}=-0.4178 ; \mathrm{p}=0.0001$; Figure $3 \mathrm{a})$ and men $(r=-0.52 ; p=0.0017$; Figure $3 b)$. No significant gender related differences in subjects' variables (Table 2), as well as in $\mathrm{B}_{\max } / \mathrm{BMI}$ ratio ( $\mathrm{fmol} \mathrm{m}^{2} / \mathrm{mg} \mathrm{Kg}$ ) were found $(\mathrm{p}=n s)$, (Figure 4). The $\mathrm{B}_{\max } / \mathrm{BMI}$ ratio was: $39.12 \pm 3.11$

Table 1 The 5 groups of BMls

\begin{tabular}{|c|c|c|c|c|c|}
\hline & Controls (NWs, $n=28$ ) & Overweight (OWs, $n=18$ ) & Obese I (OB-Is, $n=17)$ & Obese II (OB-IIs, $n=19)$ & Obese III (OB-IIIs, $n=32)$ \\
\hline \multirow[t]{2}{*}{ Age (y) } & $35.11 \pm 2.24$ & $39.42 \pm 3.10$ & $39.76 \pm 3.22$ & $36.16 \pm 2.92$ & $41.94 \pm 2.06$ \\
\hline & $(20.0-61.0)$ & $(21.0-59.0)$ & $(16.0-63.0)$ & $(20.0-61.0)$ & $(22.0-59.0)$ \\
\hline \multirow[t]{2}{*}{ BMI $\left(\mathrm{Kg} / \mathrm{m}^{2}\right)$} & $21.39 \pm 0.39$ & $27.07 \pm 0.26$ & $32.67 \pm 0.30$ & $37.52 \pm 0.34$ & $46.34 \pm 0.67$ \\
\hline & $(18.3-25)$ & $\left({ }^{* * *}\right)(25.4-28.8)$ & $\left(^{* * *}\right)(30.1-34.7)$ & $\left(^{* * *}\right)(35.5-39.8)$ & $(* * *)(40.0-54.8)$ \\
\hline
\end{tabular}

Data are presented as mean \pm S.E.M.; in parenthesis sample ranges, minimum and maximum values are shown. ANOVA BMI and post-hoc Bonferroni test: $\left(^{* * *}\right): \mathrm{p}<0.001$, NWs vs. OWs, OB-I/II/IIIs. 


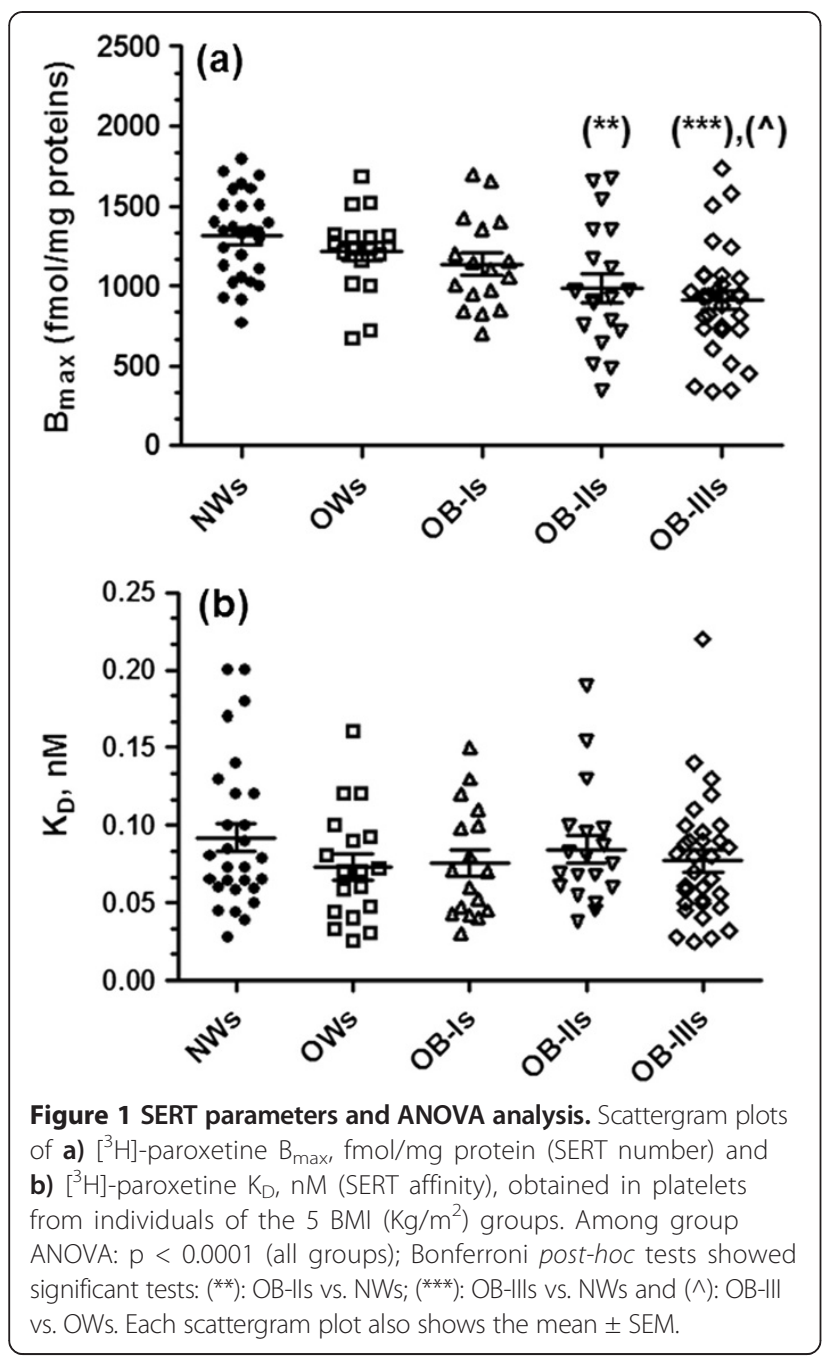

(min.-max: 9.33-74.80) in men and $36.53 \pm 2.21$ (min.max:7.92-87.06) in women. No significant variation was reported in SERT affinity $\left(\mathrm{K}_{\mathrm{D}}\right)$ among the BMI based groups (Figures $1 \mathrm{~b}$ and $2 \mathrm{~b}$ ).

\section{Discussion}

Serotonin (5-HT), primarily produced in CNS raphe nuclei and gut, plays a wide-ranging modulatory role at the level of several homeostatic responses. In particular, CNS 5-HT regulates many amongst the main individual adaptive-relational abilities to react to environmental changes, such as feeding behavior, thermoregulation, motor activity, libido, cognition, impulsivity, aggressiveness, nociception and mood. Besides, 5-HT also acts on peripheral tissues and organs, modulating the immune and flogistic responses, as well as blood stem cells differentiation, hemodynamic function and intestinal peristalsis [45]. Despite 5-HT has been extensively studied in recent years, the link between the expression of 5-HT transporter
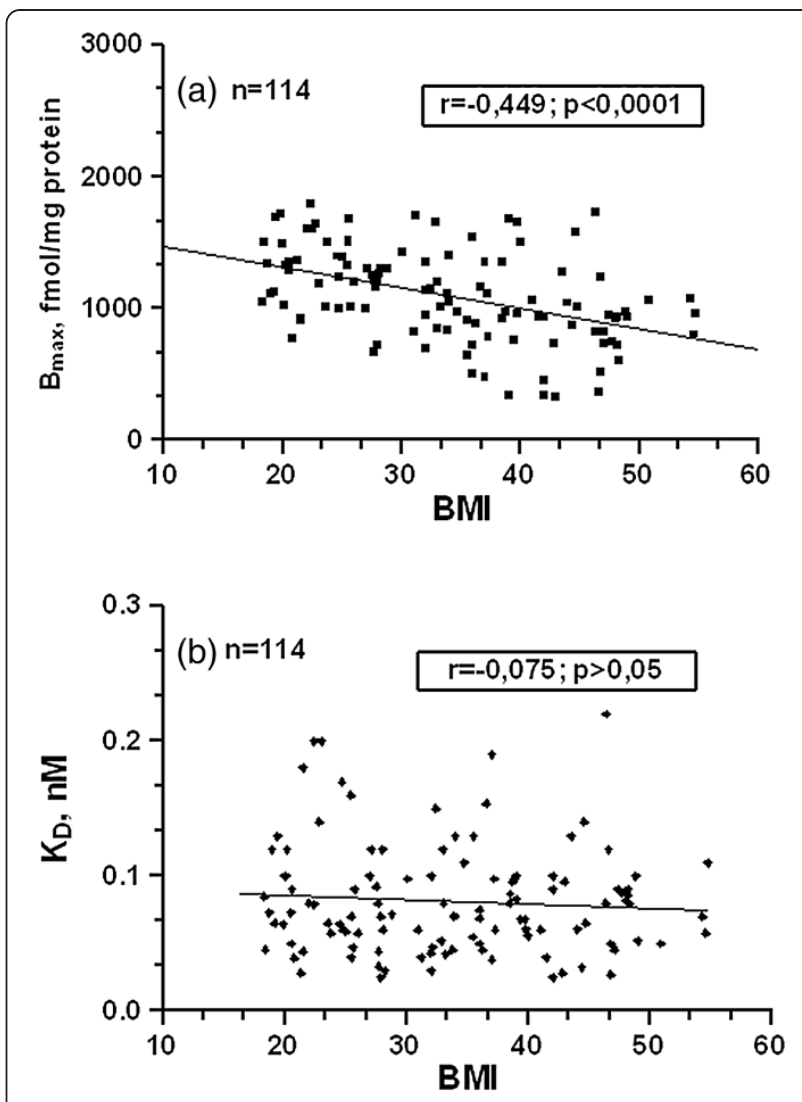

Figure 2 Correlations of platelet SERT parameters with subjects' BMI $\left(\mathrm{Kg} / \mathbf{m}^{2}\right)$. Correlations between a) $\left.{ }^{3} \mathrm{H}\right]$-paroxetine $B_{\max }(\mathrm{fmol} / \mathrm{mg}$ protein), b) $\left.{ }^{3} \mathrm{H}\right]$-paroxetine $\mathrm{K}_{\mathrm{D}}(\mathrm{nM})$ and $\mathrm{BMI}$. Panels inside figures report the corresponding Pearson $r$ coefficient and its statistical significance. Lines in $\mathbf{a}$ ) and $\mathbf{b}$ ) represents data linear fit from linear regression analysis.

(SERT), the pivotal protein regulating its extra- and intracell concentrations, and human obesity has been supported by few studies. By single-photon emission tomography (SPECT) analysis in midbrain areas of obese women affected by binge eating disorder (BED), a reduction in SERT density has been reported [46], and this reduction was rescued by SSRI therapy [47].

A more recent in vivo PET study, using a iodinate tracer $\left(\left[{ }^{123} \mathrm{I}\right]-\right.$ nor- $\beta$-CIT) in midbrain areas of monozygotic twins, has shown a higher SERT density in co-twins with higher BMI [48]. The latter study was conducted in the Finnish population, (presenting a reduced genetic variance than other human ethnic groups) and selected twins were prevalently women.

Conversely, other PET investigations on unrelated healthy volunteers using a different SERT ligand $\left(\left[{ }^{11} \mathrm{C}\right]\right.$ DASB), have shown a negative correlation between cerebral SERT expression and BMI [49,50]. Our study clearly demonstrates a reduced SERT number in platelet membranes of severely obese subjects $\left(>35 \mathrm{~kg} / \mathrm{m}^{2}\right)$ and a negative correlation between platelet SERT $B_{\max }$ and BMI 

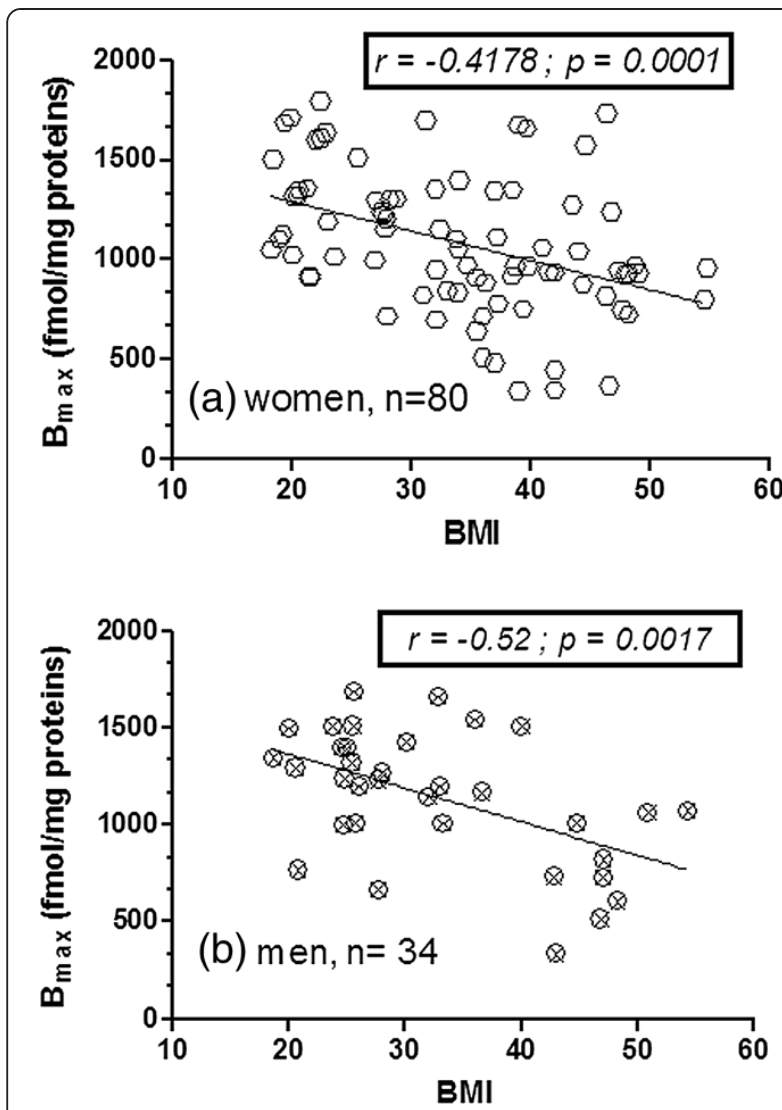

Figure 3 Correlations of platelet SERT density with BMI $\left(\mathrm{Kg} / \mathrm{m}^{2}\right)$ by gender. Correlation analysis between $\left[{ }^{3} \mathrm{H}\right]$-paroxetine $B_{\max }(\mathrm{fmol} / \mathrm{mg}$ protein) with BMl in a) women ( $n=80)$ and $\mathbf{b})$ men $(n=34)$. Panels inside figures report the Pearson $r$ coefficient and its statistical significance. Lines in $\mathbf{a}$ ) and $\mathbf{b}$ ) represents data linear fit from linear regression analysis.

in human obesity. Instead, the lack of significant changes in the SERT affinity parameter $\mathrm{K}_{\mathrm{D}}$ suggests a comparable SERT protein conformation in lean and obese individuals. All these studies substantiate the link between 5-HT activity, SERT expression and weight gain, but discrepancies are present. An explanation of this discrepancy can be found putting all these data in the context of SERT regulatory pathways.

Table 2 Gender effect on subject's variables

\begin{tabular}{ccc}
\hline & Men, $\boldsymbol{n}=\mathbf{3 4}$ & Women, $\boldsymbol{n}=\mathbf{8 0}$ \\
\hline Age (years) & $37.71 \pm 2.28$ & $38.94 \pm 1.36$ \\
& $(20.00-63.00)$ & $(15.00-61.00)$ \\
BMI (kg/m $\left.{ }^{2}\right)$ & $32.74 \pm 1.74$ & $34.05 \pm 1.11$ \\
& $(18.71-54.30)$ & $(18.30-54.80)$ \\
$\left.{ }^{3} \mathbf{H}\right]$-paroxetine $\mathbf{B}_{\text {max }}$ & $1142 \pm 58.31$ & $1085 \pm 39.02$ \\
(fmol/mg protein) & $(336-1685)$ & $(344-1795)$ \\
$\left.{ }^{3} \mathbf{H}\right]$-paroxetine $K_{\mathbf{D}}$ (nM) & $0.071 \pm 0.006$ & $0.085 \pm 0.005$ \\
& $(0.028-0.170)$ & $(0.025-0.220)$ \\
\hline
\end{tabular}

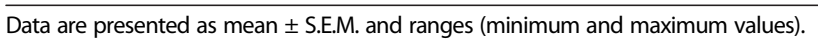

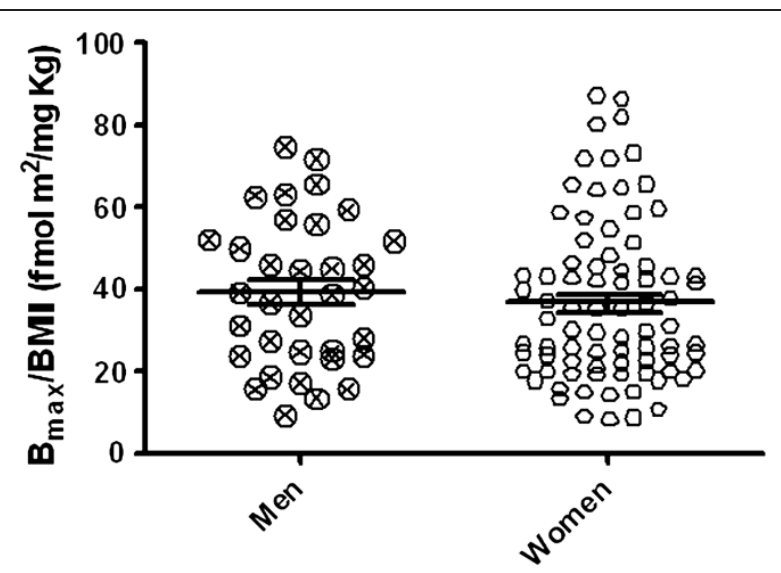

Figure 4 Comparison of $\left[^{3} \mathrm{H}\right]$-paroxetine $\mathrm{B}_{\max } / \mathrm{BMI}$ ratios (SERT density/BMI, fmol $\mathrm{m}^{2} / \mathrm{mg} \mathrm{Kg}$ ), in males and females. Scattergram plots of $\left[{ }^{3} \mathrm{H}\right]$-paroxetine $\mathrm{B}_{\max } / \mathrm{BMl}$ ratios obtained in men and women. Each scattergram plot also shows the mean \pm SEM.

As introduced before, protein SERT expression is a model of "fine-tuned" regulation of membrane-bound proteins. Beside undergoing a short-term up and downregulation, SERT presence in cell membranes can be longterm modulated through positive and negative signals, allowing long-lasting cell adaptation to the extracellular content of 5-HT or other related stimuli. The balance between the converging short and long-term regulatory pathways of SERT defines its expression and affinity states during developmental stages, under physiological and pathological conditions.

We have previously shown that SERT protein expression in platelets (in plasma membrane and intracellular pools) is regulated by megakaryoblast cell differentiation processes [51]. We have also reported an up-regulated translocator protein TSPO expression in discrete brain regions of $o b / o b$ mice, without appreciable changes in SERT number either in the brain or in platelets [52]. Since leptin has been found to down-regulate SERT expression [53], we hypothesized that $o b / o b$ animals, during their development, can modulate SERT expression through the activation of alternative regulatory pathways, without excluding modified SERT reserve and 5-HT responsiveness. In the present study, a reduced platelet SERT in severe obese subjects (grade II and III) has been shown. This finding mirrors at the peripheral levels what previously reported in the brain [50]. In contrast to mutant leptinlacking $o b / o b$ mice, a link between human obesity, often associated with high serum leptin $[54,55]$ and SERT regulatory cascades leading to its reduction or internalization can be hypothesized. The implications of regulatory mechanisms on reduced SERT expression in obesity is indirectly supported by studies conducted on double knockout SERT(-/-)/brain derived neurotrophic factor (BDNF) (+/-) mice $[56,57]$ revealing the regulatory role 
of either other monoamine protein markers or trophic factors on 5-HT physiology and activity on body weight balance. Nevertheless, currently, a clear explanation for the lower SERT expression found in platelets of severe obese individuals is lacking. Platelet $5-\mathrm{HT}$ can be part of a network involving adipokines, cytokines and inflammatory responses [58]. This is supported by the report of adipocytes expressing 5-HT receptor subtypes [59] and, more recently, even SERT [60], suggesting that adipose tissue and 5-HT system interact with each other. It is possible that the reduced SERT expression is due to impaired $5-\mathrm{HT}$ synthesis and activity in obese subjects $[3,61]$, as reported for neurotic behaviors and personality traits, and that altered SERT/5-HT receptors and/or SERT regulation underscore obesity. In this study, none of the recruited subjects had a present or past history of a major psychiatric disorder, but some of them could present personality traits that could be possibly linked to susceptibility to obesity $[57,62]$. On the other side, imbalanced appetite hormones, adipokines or gut hormones could counterregulate SERT expression.

The controversy between reduced SERT expression in obese subjects and increased midbrain SERT in acquired obesity, as reported in monozygotic co-twins with a higher BMI [48], can be explained by different SERT regulatory processes during gene-environment interactions. Specifically, the selection criteria applied in the Finnish study could have included higher BMI co-twins under particular lifestyles and/or changes of dietary habits leading to SERT up-regulation, as observed in rodent models of acquired obesity [63]. At the same time, considering the experimental design of the Finnish study, selected twins could also bear a genotype linked to vulnerability to stress as SERT-reducing obese subjects [64]. Moreover, of note, our investigation and that by Erritzoe et al. (2011) [50] much differ from the Finnish study [48] in terms of: a) evaluated BMI ranges; b) employed technical procedures (e.g., PET vs. in vitro binding experiments carried in membranes; different SERT binding tracers); c) sample size of recruited subjects.

Despite the well-known gender-related differences in obesity and fat distribution, we did not found appreciable differences in $\mathrm{B}_{\max } / \mathrm{BMI}$ ratios in males vs. females, suggesting a gender-independent effect of BMI on SERT expression in platelets of severe obese individuals.

\section{Conclusions}

Analyzing the biggest cohort of the literature so far, our study demonstrates, for the first time, that SERT density is reduced in plasma membranes of circulating platelets of severe (class II/III, BMI $>35 \mathrm{~kg} / \mathrm{m}^{2}$ ) obese subjects, without gender-related differences. Nevertheless, the complexity of SERT regulation needs to be investigated further. A multivariate statistical elaboration in normal, overweight and obese subjects is currently in progress in order to better define the contribution of energy metabolism/adipocyte function on the modulation of platelet SERT (number and function) in obese individuals. Moreover, we suggest to better evaluate the role of 5 -HT in body weight balance through the measure of other parameters such as 5-HT re-uptake function, intraplatelet/bloodstream 5-HT levels, intra-platelet SERT content, plasma large-neutral amino acids, BDNF, TSPO as well as the binding and sensitization state of 5-HT receptor subtypes in obese subjects. Microarray gene, peptide/protein analyses and metabolomics would be helpful to identify involved signals, effectors and regulatory cascades, also in other SERT expressing districts such as the gut or adipose tissue. The targeting of 5-HT-related gene/ proteins and other monoamine or endocrine biomarkers would help to detect different subtypes of human obesity, possibly triggered by distinct biological causes, allowing the development of novel therapeutic strategies.

\section{Methods \\ Chemicals}

$\left[{ }^{3} \mathrm{H}\right]$-paroxetine (specific activity: $15.5 \mathrm{Ci} / \mathrm{mmol}$ ) was purchased from Perkin-Elmer, Life Science, Milan, Italy. All other reagents were of the best analytical grade.

\section{Subjects}

One hundred and fourteen (Italian) subjects (34 M; $80 \mathrm{~W}$; age: $38.57 \pm 12.47$ years) with a BMI ranging between 18.30 and $54.80 \mathrm{Kg} / \mathrm{m}^{2}\left(33.54 \pm 9.923 \mathrm{Kg} / \mathrm{m}^{2}\right)$ were enrolled for the present study. Normal weight subjects were recruited from the medical and laboratory staff of the Endocrinology Center. Overweight and obese $\left(\mathrm{BMI}>25 \mathrm{Kg} / \mathrm{m}^{2}\right)$ subjects were recruited among the patients of the Obesity Center, Endocrinology Unit 1, University of Pisa. Exclusion criteria were: active cancer, heart, liver or kidney diseases; presence of hematological or neurological illnesses, a positive history for substance abuse and psychiatric (Axis I) disorders assessed by Structured Clinical Interview for DSM-IV Axis-I diseases (SCID/I diagnostic criteria).

Subjects assuming substances acting on SERT, other psychotropic agents or estro-progestinic drugs and NonSteroidal Anti-Inflammatory Drugs (NSAIDs) were admitted to the study after a 3 months and 10 long days withdrawal, respectively. Assuming hypotensive or interfering with carbohydrate-lipid metabolism (insulin, oral hypoglycemic compounds, statines) drugs was an exclusion criteria as well.

Height was measured, while subjects were standing, using standardized techniques and equipment. Body weight was measured by a precision instrument and electronic scale $( \pm 0.1 \mathrm{Kg})$. A regular informed consent approved by the Ethics Committee of the Pisa University was signed by all subjects after reading a full explanation of the project. 


\section{Platelet sampling}

To avoid catecholamine release as well as circadian rhythm interference, peripheral venous blood $(30 \mathrm{ml})$ was drawn from fasting subjects in clinostat position between 8.30 and 10 a.m. Blood was collected into plastic tubes containing $5 \mathrm{ml}$ of anticoagulant (2.2\% sodium citrate, $1.2 \%$ citric acid) and centrifuged at low-speed $(150 \mathrm{~g})$ for $15 \mathrm{~min}$ at $23^{\circ} \mathrm{C}$ to separate the platelet rich plasma (PRP). Platelets were then precipitated from PRP by an ensuing centrifugation at 1,500 g for 15 min at $23^{\circ} \mathrm{C}$ and counted automatically with a flux cytometer (Cell-dyn 3500 system; Abbott, Milano, Italy). Platelets were then washed by centrifugation for $10 \mathrm{~min}$ at $10,000 \mathrm{~g}, 4^{\circ} \mathrm{C}$ and resulting pellets stored at $-80^{\circ} \mathrm{C}$ until assay, performed within 1 week.

\section{Platelet membrane preparation}

At the time of the assay, platelets were re-suspended in 10 volumes (w:v) ice-cold $5 \mathrm{mM}$ Tris- $\mathrm{HCl}$ buffer $(\mathrm{pH} 7.4)$ containing $5 \mathrm{mM}$ EDTA and protease inhibitors (benzamidine $160 \mu \mathrm{g} / \mathrm{ml}$, bacitracine $200 \mu \mathrm{g} / \mathrm{ml}$; trypsine soy inhibitor $20 \mu \mathrm{g} / \mathrm{ml})$. After homogenization by Ultraturrax, samples were centrifuged at 48,000 g for 15 minutes at $4^{\circ} \mathrm{C}$. The ensuing pellets were washed twice in 10 volumes $(w: v)$ ice-cold $50 \mathrm{mM}$ Tris- $\mathrm{HCl}$ buffer ( $\mathrm{pH} \mathrm{7.4)} \mathrm{by} \mathrm{a} \mathrm{centrifu-}$ gation step, as above indicated. The final membrane pellets were suspended in the assay buffer consisting in a $50 \mathrm{mM}$ Tris- $\mathrm{HCl}$ buffer ( $\mathrm{pH} 7.4$ ), containing $120 \mathrm{mM}$ $\mathrm{NaCl}$ and $5 \mathrm{mM} \mathrm{KCl}$. Protein content was determined by the Bradford's method (Bio-rad), using $\gamma$-globulins as the standard.

\section{$\left[{ }^{3} \mathrm{H}\right]$-Paroxetine binding assay}

SERT binding parameters (maximal binding capacity, $\mathrm{B}_{\max }$, $\mathrm{fmol} / \mathrm{mg}$ protein; dissociation constant, $K_{D}, \mathrm{nM}$ ) were evaluated in platelet membranes by measuring the specific binding of $\left[{ }^{3} \mathrm{H}\right]$-paroxetine. The $\left[{ }^{3} \mathrm{H}\right]$-paroxetine $\mathrm{B}_{\max }$ represents the specific density (number) or the degree of SERT protein expression on platelet membranes of each enrolled subject, while $K_{\mathrm{D}}$ being the main index of ligand-to-protein affinity. Saturation experiments were conducted as follows: $100 \mu \mathrm{l}$ of membranes (corresponding to $50-100 \mu \mathrm{g}$ proteins/tube) were incubated in assay buffer $(50 \mathrm{mM}$ Tris- $\mathrm{HCl}, 5 \mathrm{mM} \mathrm{KCl}, 120 \mathrm{mM} \mathrm{NaCl}$, $\mathrm{pH}$ 7.4) with five increasing concentrations of $\left[{ }^{3} \mathrm{H}\right]$-paroxetine (0.08-1.5 $\mathrm{nM}$ ) in a final assay volume of $2 \mathrm{ml}$. Non-specific binding was performed, for each $\left[{ }^{3} \mathrm{H}\right]$-paroxetine concentration point, in the presence of $10 \mu \mathrm{M}$ fluoxetine, as cold displacer. Incubation was performed at $22-24^{\circ} \mathrm{C}$ for $60 \mathrm{~min}$ and halted by rapid filtration using Whatman GF/C glass fiber filters in a Brandell filtration apparatus. Filters were then washed three times with $5 \mathrm{ml}$ ice-cold buffer assay, put into pony vials and measured for radioactivity $(\mathrm{dpm})$ through a liquid phase scintillation $\beta$-counter Packard 1600 TR. Specific binding was obtained by subtracting residual binding in the presence of $10 \mu \mathrm{M}$ fluoxetine from total binding.

\section{Data analysis}

For statistical analyses, the subjects were divided into groups according to BMI classes: normal-weight (NW, controls), overweight (OW) and grade I-III obese (OB) individuals [65]. Equilibrium-saturation binding data, maximum binding capacity (Bmax, fmol/mg of protein) and dissociation constant $\left(K_{D}, n M\right)$, were calculated by the iterative curve-fitting computer programs EBDA-LIGAND (Kell for Windows, v. 6.0) [66] and Graph-Pad Prism (version 3 and 5, San Diego, CA, USA). Results of descriptive statistical analyses were reported as the mean \pm the Standard Error of the Mean (S.E.M.), when not differently indicated in the text. For inferential analyses relating SERT expression and affinity with obesity ANOVA followed by the Bonferroni post-hoc test as well as $t$-test Student for unpaired data (gender influence) were used; Pearson correlations analyses and linear regression tests between platelet $\left[{ }^{3} \mathrm{H}\right]$-paroxetine binding parameters and BMI values were also performed in men and women separately between platelet $\left[{ }^{3} \mathrm{H}\right]$-paroxetine binding parameters and BMI values were also performed in men and women separately. For gender-specific $t$-test analysis, binding densities were normalized for BMI in women and men separately, obtaining $B_{\max } / B M I$ values $\left(\mathrm{fmol} \times \mathrm{m}^{2}\right.$ height squared/mg proteins $\times \mathrm{Kg}$ body weight). For all statistical analyses, Graph-Pad Prism software was used and the significance threshold was set at $\mathrm{p}=0.05$.

\section{Competing interests}

The authors declare that they have no competing interests.

\section{Authors' contributions}

GG and AL conceived the study, participated to its design and coordinated all the study steps; FS, MM and PV participated to the study development while FS, AM, MMr and PF recruited and clinically evaluated the subjects; LB, $L F, L S$ and $M L$ conducted binding assays; CP and SB were responsible of blood sampling and processing; LP, LF, LG and MC elaborated experimental results; $L P, L B$ and $A M$ wrote the manuscript. All authors read and approved the final manuscript.

\section{Acknowledgements}

The present work has been supported by: "Ministero dell'Istruzione dell'Università e della Ricerca" (M.I.U.R) - Italian Government- as grants to Prof. G. Giannaccini.

\section{Author details}

'Department of Pharmacy, University of Pisa, via Bonanno 6, Pisa 56126-I, Italy. ${ }^{2}$ Department of Clinical and Experimental Medicine, University of Pisa, Via Savi 10, 56126-I, Pisa, Italy. ${ }^{3}$ Clinical Pharmacology Unit, University Hospital "Santa Chiara", Via Savi 10, 56126-I, Pisa, Italy. "Insitute of "Fisiologia Clinica", CNR, Via G. Moruzzi 1, 56124, Pisa, Italy. "Endocrinology Unit, University Hospital of Cisanello, via Paradisa 2, Pisa, Italy.

Received: 6 March 2013 Accepted: 9 October 2013

Published: 18 October 2013 


\section{References}

1. Leibowitz SF, Alexander JT: Hypothalamic serotonin in control of eating behaviour, meal size and body weight. Biol Psychiatry 1989, 44:851-864.

2. Schwartz DH, Hernandez L, Hoebel BG: Serotonin release in lateral and ventral hypothalamus during feeding and its anticipation. Brain Res Bull 1990, 25:797-802.

3. Blundell JE: Serotonin and the biology of feeding. Am J Clin Nutr 1992, 55:1555-1595.

4. Gessa GL, Biggio G, Fadda F, Corsini GU, Tagliamonte A: Effect of the oral administration of tryptophan-free amino acid mixtures on serum tryptophan, brain tryptophan and serotonin metabolism. J Neurochem 1974, 22:869-870.

5. Caballero B, Finer N, Wurtman RJ: Plasma amino acids and insulin levels in obesity: response to carbohydrate intake and tryptophan supplements. Metab 1988, 37:672-676

6. Benton D: Carbohydrate ingestion, blood glucose and mood. Neur Biobehav Rev 2002, 26:293-308

7. Kendzor D, Appelhans B, Hedeker D, Pagoto S: Abuse potential of carbohydrates for overweight carbohydrate cravers. Psychopharmacology (Berl) 2008, 197:637-647.

8. Wurtman RJ: Non-nutritional uses of nutrients. Eur J Pharmacol 2011, 668:S10-S15.

9. Fernstrom JD: Large neutral amino acids: dietary effects on brain neurochemistry and function. Amino Acids 2012. 10.1007/s00726-012-1330-y

10. Ely DR, Dapper V, Marasca J, Correa JB, Gamaro GD, Xavier MH: Effect of restraint stress on feeding behavior of rats. Physiol Behav 1997, 61:395-398.

11. Van de Kar LD, Blair ML: Forebrain pathways mediating stress-induced hormone secretion. Front Neuroendocrinol 1999, 20:1-48

12. Carrasco GA, Van der Kar LD: Neuroendocrine pharmacology of stress. Eur J Pharmacol 2003, 463:235-272.

13. Torres $S$, Nowson C: Relationship between stress, eating behavior and obesity. Nutr 2007, 23:887-894

14. Barsh GS, Faroogi S, O'Rahilly S: Genetics of body weight regulation. Nat 2000, 404:644-651.

15. Yang W, Kelly T, He J: Genetic epidemiology of obesity. Epidemiol Rev 2007, 29:49-61.

16. Bell CG, Walley AJ, Froguel P: The genetics of human obesity. Nature Rev Gen 2005, 6:221-234.

17. Lam DD, Heisler LK: Serotonin and energy balance: molecular mechanisms and implications for type 2 diabetes. Expert Rev Mol Med 2007, 9:1-24.

18. Sookoian S, Gemma C, García SI, Gianotti TF, Dieuzeide G, Roussos A, Tonietti M, Trifone L, Kanevsky D, González CD, Pirola CJ: Short allele of serotonin transporter gene promoter is a risk factor for obesity in adolescents. Obesity (Silver Spring) 2007, 15:271-276.

19. Sookoian S, Gianotti TF, Gemma C, Burgueño A, Pirola CJ: Contribution of the functional 5-HTTLPR variant of the SLC6A4 gene to obesity risk in male adults. Obesity (Silver Spring) 2008, 16:488-491.

20. Fuemmeler BF, Agurs-Collins TD, McClernon FJ, Kollins SH, Kail ME, Bergen AW, Ashley-Koch AE: Genes implicated in serotonergic and dopaminergic functioning predict BMI categories. Obesity (Silver Spring) 2008, 16:348-355.

21. Garfield AS, Heisler LK: Pharmacological targeting of the serotonergic system for the treatment of obesity. J Physiol 2009, 587(Pt 1):49-60.

22. Suviolahti E, Oksanen LJ, Ohman M, Cantor RM, Ridderstrale M, Tuomi T, Kaprio J, Rissanen A, Mustajoki P, Jousilahti P, Vartiainen E, Silander K, Kilpikari R, Salomaa V, Groop L, Kontula K, Peltonen L, Pajukanta P: The SLC6A14 gene shows evidence of association with obesity. J Clin Invest 2003, 112:1762-1772.

23. Tecott LH, Sun LM, Akana SF, Strack AM, Lowenstein DH, Dallman MF, Julius D: Eating disorder and epilepsy in mice lacking $5-\mathrm{HT}_{2 \mathrm{C}}$ serotonin receptors. Nat 1995, 374:542-546.

24. Heisler $L K$, Chu H, Tecott $L H$ : Epilepsy and obesity in serotonin $5-H T 2 C$ receptor mutant mice. Ann NY Acad Sci 1998, 861:74-78,

25. Aubert R, Betoulle D, Herbeth B, Siest G, Fumeron F: $5-\mathrm{HT}_{2 \mathrm{~A}}$ receptor gene polymorphism is associated with food and alcohol intake in obese people. Int J Obes Relat Metab Disord 2000, 24:920-924.

26. Bouwknecht JA, van der Gugten J, Hijzen TH, Maes RA, Hen R, Olivier B: Male and femal $5-\mathrm{HT}_{1 \mathrm{~B}}$ receptor knockout mice have higher body weights than wild types. Physiol Behav 2001, 74:507-516.

27. Woolley ML, Bentley JC, Sleight AJ, Mardsen CA, Fone KC: A role for 5-HT6 receptors in retention of spatial learning in the Morris water maze. Neuropsychopharmacol 2001, 41:210-219.
28. Bechtholt B, Smith K, Gaughan S, Lucki I: Sucrose intake and fasting glucose levels in $5-\mathrm{HT}_{1 \mathrm{~A}}$ and $5-\mathrm{HT}_{1 \mathrm{~B}}$ receptor mutant mice. Physiol Behav 2008, 93:659-665.

29. Leibowitz SF, Alexander JT, Cheung WK, Weiss GF: Effects of serotonin and the serotonin blocker metergoline on meal patterns and macronutrient selection. Pharmacol Biochem Behav 1993, 45:185-194.

30. Corsica JA, Spring BJ: Carbohydrate craving: a double-blind, placebocontrolled test of the self-medication hypothesis. Eat Behav 2008, 9:447-454.

31. Marazziti D, Rossi A, Giannaccini G, Baroni S, Lucacchini A, Cassano GB: Presence and characterization of the serotonin transporter in human resting lymphocytes. Neuropsychopharmacol 1998, 19:154-159.

32. Iceta R, Mesonero JE, Aramayona JJ, Alcalde A: Molecular characterization and intracellular regulation of the human serotonin transporter in Caco-2 cells. J Physiol Pharmacol 2006, 57:119-130.

33. Rothman RB, Blough BE, Baumann MH: Dual DA/5-HT releasers: potential treatment agents for stimulant addiction. Exp Clin Psychopharmacol 2008 16:458-474.

34. Zahniser NR, Doolen S: Chronic and acute regulation of $\mathrm{Na}+/ \mathrm{Cl}$ - dependent neurotransmitter transporters: drugs, substrates, presynaptic receptors, and signaling systems. Pharmacol Ther 2001, 92:21-55.

35. Zhu CB, Hewlett WA, Feoktistov I, Biaggioni I, Blakely RD: Adenosine receptor, protein kinase $G$, and $p 38$ mitogen-activated protein kinasedependent up-regulation of serotonin transporters involves both transporter trafficking and activation. Mol Pharmacol 2004, 65:1462-1474.

36. Carneiro AM, Blakely RD: Serotonin, protein-kinase C-, and Hic-5associated redistribution of the platelet serotonin transporter. $J$ Biol Chem 2006, 281:24769-24780.

37. Ramamoorthy S, Samuvel DJ, Buck ER, Rudnick G, Jayanthi LD: Phosphorylation of threonine residue 276 is required for acute regulation of serotonin transporter by cyclic GMP. J Biol Chem 2007, 282:11639-11647.

38. Mellerup ET, Plenge $P$, Engelstoft M: High affinity binding of $\left[{ }^{3} \mathrm{H}\right]$-Paroxetine and $\left[^{3} \mathrm{H}\right]-$ Imipramine to human platelet membranes. Eur J Pharmacol 1983, 96:303-309.

39. Stahl SM: The human platelet: A diagnostic and research tool for the study of biogenic amines in psychiatry. Arch Gen Psychiatry 1997, 34:509-516.

40. Aharanovitz O, Granot Y: Stimulation of mitogen-activated protein kinase and $\mathrm{Na}^{+} / \mathrm{H}^{+}$exchanger in human platelets. J Biol Chem 1996, 271:16494-16499.

41. Marazziti D, Baroni S, Rossi A, Masala I, Giannaccini G, Gori V, Lucacchini A, Cassano GB: Pharmacological characterization of the serotonin transporter in young and elderly subjects. Neuropsychobiology 2001, 44:78-83.

42. Ramacciotti CE, Coli E, Paoli R, Marazziti D, Dell'Osso L: Serotonergic activity measured by platelet ${ }^{3} \mathrm{H}$-paroxetine binding in patients with eating disorders. Psychiatry Res 2003, 118:33-38.

43. Tardito D, Mori S, Racagni G, Smeraldi E, Zanardi R, Perez J: Protein kinase A activity in platelets from patients with bipolar disorder. J Affect Dis 2003, 76:249-253.

44. Martini C, Trincavelli ML, Tuscano D, Carmassi C, Ciapparelli A, Lucacchini A, Cassano GB, Dell'Osso L: Serotonin mediated phosphorylation of extracellular regulated kinases in platelets of patients with panic disorder versus controls. Neurochem Int 2004, 44:627-639.

45. Mohammad-Zadeh LF, Moses L, Gwaltney-Brant SM: Serotonin: a review. J Vet Pharmacol Ther 2008, 31:187-199.

46. Kuikka JT, Tammela L, Karhunen L, Rissanen A: Reduced serotonin transporter binding in binge eating women. Psychopharmacology (Berl) 2001, 155:310-314.

47. Tammela LI, Rissanen A, Kuikka JT, Karuhnen LJ, Bergstrøm KA, Repo-Tihonen E, Naukkarinen $\mathrm{H}$, Vanninen $\mathrm{E}$, Tiihonen $\mathrm{Y}$, Uusitupa M: Treatment improves serotonin transporter binding and reduces binge eating. Psychopharmacology (Berl) 2003, 170:89-93.

48. Koskela AK, Kaurijoki S, Pietiläinen KH, Karhunen L, Pesonen U, Kuikka JT, Kaprio J, Rissanen A: Serotonin transporter binding and acquired obesity - An imaging study of monozygotic twin pairs. Physiol Behav 2008, 93:724-732.

49. Matsumoto R: Inverse correlation between body mass index and serotonin transporter in human brain: A $\left[{ }^{11} \mathrm{C}\right] \mathrm{DASB}$ PET study. Neuroimage 2008, 41 (Suppl 2):T161.

50. Erritzoe D, Frokjaer VG, Haahr MT, Kalbitzer J, Svarer C, Holst KK, Hansen DL, Jernigan TL, Lehel S, Knudsen GM: Cerebral serotonin transporter binding is inversely related to body mass index. Neuroimage 2010, 52:284-289. 
51. Giannaccini G, Betti L, Palego L, Schmid L, Fabbrini L, Pelosini C, Gargini C, Da Valle Y, Lanza M, Marsili A, Maffei M, Santini F, Vitti P, Pinchera A, Lucacchini A: Human Serotonin Transporter Expression during Megakaryocytic Differentiation of MEG-01 Cells. Neurochem Res 2010, 35:628-635.

52. Giannaccini G, Betti L, Palego L, Pirone A, Schmid L, Lanza M, Fabbrini L, Pelosini C, Maffei M, Santini F, Pinchera A, Lucacchini A: Serotonin transporter (SERT) and translocator protein (TSPO) expression in the obese ob/ob mouse. BMC Neurosci 2011, 12:18.

53. Charnay $Y$, Cusin I, Vallet PG, Muzzin P, Rohner-Jeanrenaud F, Bouras $C$ : Intracerebroventricular infusion of leptin decreases serotonin transporter binding sites in the frontal cortex of the rat. Neurosci Lett 2000, 283:89-92.

54. Maffei M, Halaas J, Ravussin E, Pratley RE, Lee GH, Zhang Y, Fei H, Kim S, Lallone $R$, Ranganathan $S$, et al: Leptin levels in human and rodent: measurement of plasma leptin and ob RNA in obese and weight-reduced subjects. Nat Med 1995, 1:1155-1161.

55. Considine RV, Sinha MK, Heiman ML: Serum immunoreactive-leptin concentrations in normal-weight and obese humans. N Engl J Med 1996, 334:292-295.

56. Murphy DL, Uhl GR, Holmes A, Ren-Patterson R, Hall FS, Sora I, Detera-Wadleigh Lesch KP: Experimental gene interaction studies with SERT mutant mice as models for human polygenic and epistatic traits and disorders. Genes Brain Behav 2003, 2:350-364.

57. Gardier AM: Mutant mouse models and antidepressant drug research: focus on serotonin and brain derived neurotrophic factor. Behavioral Pharmacol 2009, 20:18-32.

58. Matarese G, La Cava $A$ : The intricate interface between immune system and metabolism. Trends Immunol 2004, 25:193-200.

59. Kinoshita M, Ono K, Horie T, Nagao K, Nishi H, Kuwabara Y, Takanabe-Mori R, Hasegawa K, Kita T, Kimura T: Regulation of adipocyte differentiation by activation of serotonin (5-HT) receptors $5-\mathrm{HT}_{2 \mathrm{AR}}$ and $5-\mathrm{HT}_{2 \mathrm{CR}}$ and involvement of microRNA-448-mediated repression of KLF5. Mol Endocrinol 2010, 24:1978-1987.

60. Stunes AK, Reseland JE, Hauso O, Kidd M, Tømmerås K, Waldum HL, Syversen $U$, Gustafsson BI: Adipocytes express a functional system for serotonin synthesis, reuptake and receptor activation. Diabetes Obes Metab 2011, 13:551-558.

61. Breum L, Rasmussen MH, Hilsted J, Fernstrom JD: Twenty-four-hour- plasma tryptophan concentrations and ratios are below normal in obese subjects and are not normalized by substantial weight reduction. Am J Clin Nutr 2003, 77:1112-1118.

62. Hariri $A R$, Holmes A: Genetic of emotional regulation: the role of serotonin transporter in neural function. Trends Cogn Sci 2006, 10:182-191.

63. Park SY, Harrold JA, Widdowson PS, Williams G: Increased binding at $5-\mathrm{HT}_{1 \mathrm{~A},}$ $5-\mathrm{HT}_{1 \mathrm{~B}}$ and $5-\mathrm{HT}_{2 \mathrm{~A}}$ receptors and 5-HT transporter in diet-induced obese rats. Brain Res 1999, 847:90-97.

64. Tripp A, Sibille E: SERT models of emotional dysregulation. In Experimental Models in Serotonin Transporter Research. Edited by Kalueff AV, Laporte JL. Cambridge, UK: Cambridge University Press; 2009:105-135.

65. Obesity: preventing and managing the global epidemic. Report of a WHO consultation. World Health Organ Tech Rep Ser 2000, 894:1-253.

66. Mc Pherson GA, Grant A: Analysis of radioligand binding experiments, a collection of computer programs for IBM PC. J Pharmacol Methods 1985 14:213-288.

doi:10.1186/1471-2202-14-128

Cite this article as: Giannaccini et al:: The expression of platelet serotonin transporter (SERT) in human obesity. BMC Neuroscience 2013 14:128

\section{Submit your next manuscript to BioMed Central and take full advantage of:}

- Convenient online submission

- Thorough peer review

- No space constraints or color figure charges

- Immediate publication on acceptance

- Inclusion in PubMed, CAS, Scopus and Google Scholar

- Research which is freely available for redistribution 